\title{
Population Diversity and Sensitivity to Azoxystrobin of Alternaria brassicicola in New York State
}

Rachel A. Kreis, Plant Pathology and Plant-Microbe Biology Section, School of Integrative Plant Science, Cornell University, Geneva, NY 14456; Helene R. Dillard, College of Agricultural and Environmental Sciences, University of California, Davis, CA 95616; and Christine D. Smart, Plant Pathology and Plant-Microbe Biology Section, School of Integrative Plant Science, Cornell University, Geneva, NY 14456

\begin{abstract}
Kreis, R. A., Dillard, H. R., and Smart, C. D. 2016. Population diversity and sensitivity to azoxystrobin of Alternaria brassicicola in New York State. Plant Dis. 100:2422-2426.

Alternaria brassicicola is the causal agent of Alternaria leaf spot, a common disease of brassica crops in New York State. New York isolates of A. brassicicola were collected from a variety of brassica crops and locations to evaluate the population diversity and screen for fungicide sensitivity. Isolates were genotyped for 10 microsatellite loci and assayed for sensitivity to azoxystrobin, a quinone outside inhibitor fungicide. The New York State population of A. brassicicola was found to have high levels of genotypic diversity

and the population was found to be in linkage disequilibrium. Based on in vitro assays, the effective concentrations of azoxystrobin reducing spore germination by $50 \%$ ranged from 0.22 to $14.12 \mu \mathrm{g} / \mathrm{ml}$. In order to confirm the sensitivity of 47 isolates to azoxystrobin, the $c y t b$ gene was characterized and sequenced to determine whether any of the mutations known to confer resistance to azoxystrobin were present. The mutations F129L, G137R, and G143A were not detected in the isolates studied.
\end{abstract}

New York State is the second largest producer of fresh-market cabbage (Brassica oleracea var. capitata) in the United States, with 8,300 acres harvested in 2014 for a value of $\$ 72$ million (USDA 2015). New York producers also grow fresh-market cauliflower (B. oleracea var. botrytis) and processing cabbage along with many other minor brassica crops intended for the fresh market. An economically important pathogen for cultivated brassica crops is Alternaria brassicicola (Schwein.) Wiltshire, causal agent of Alternaria leaf spot. The disease begins with small black lesions $(1 \mathrm{~mm})$ on the leaves that enlarge over time to form concentric bull's eye lesions. The disease can appear on the harvested portion of the crop, resulting in a damaged and unmarketable crop, and is especially noticeable in cauliflower curds, where black spots appear on the white florets.

The climate of New York State is an ideal environment for A. brassicicola which has optimal sporulation at temperatures between 20 to $30^{\circ} \mathrm{C}$ and a relative humidity of at least $87 \%$ (HumphersonJones and Phelps 1989). A. brassicicola epidemics can also start the following growing season due to seed transmission and survival on crop debris (Humpherson-Jones 1989; Köhl et al. 2011, 2010). A. brassicicola produces conidia that are dispersed by wind and rain splash (Chen et al. 2003). Infection can also spread during the growing season through insects and weed species (Cobb and Dillard 1998; Dillard et al. 1998).

A. brassicicola is thought to reproduce primarily through asexual reproduction. Although no sexual stage has been found, high levels of diversity have been observed in A. brassicicola populations in Australia (Bock et al. 2005; Linde et al. 2010). The authors suggested that recombination was occurring occasionally for A. brassicicola. Bock et al. (2005) found high levels of genetic diversity for five populations of A. brassicicola in Australia infecting Cakile maritima using amplified fragment length polymorphisms indicative of a randomly mating population; however, the populations studied were in linkage disequilibrium, suggesting that some clonality exists among

Corresponding author: C. D. Smart; E-mail: cds14@cornell.edu

Accepted for publication 22 July 2016.

http://dx.doi.org/10.1094/PDIS-03-16-0414-RE

(C) 2016 The American Phytopathological Society the populations. Linkage disequilibrium is a measurement of the nonrandom association of alleles at different loci; however, high levels of genotypic diversity along with gene diversity can be an indication of recombination (Milgroom 1996).

Another study used microsatellites to look at A. brassicicola populations from C. maritima in Australia and also found high levels of genetic diversity and gene diversity (Linde et al. 2010). Similarly, other studies on Alternaria spp. have also found high levels of diversity, including A. alternata on pear, pistachio, potato, tomato, and citrus along with indoor allergen samples (Adachi et al. 1993; Aradhya et al. 2001; Meng et al. 2015a; Morris et al. 2000; Stewart et al. 2013; Woudenberg et al. 2015). High levels of diversity have also been found in A. solani on tomato and potato (Meng et al. 2015b; van der Waals et al. 2004). However, little was known about the diversity of the upstate New York population of A. brassicicola.

Growers in New York State commonly use strobilurin fungicides such as azoxystrobin to control for Alternaria leaf spot, making one or two sprays per season during peak disease in the fall. There have been no obvious control failures; however, there is always concern about the potential for resistant isolates to be present in the pathogen population. Azoxystrobin, a quinone outside inhibitor (QoI) fungicide, has a single-site mode of action. Azoxystrobin inhibits mitochondrial respiration by binding to the Qo site of cytochrome $b$ $(c y t b)$, blocking electron transfer between $c y t b$ and cytochrome $c$ and, thus, disrupting the energy cycle by prohibiting ATP production (Bartlett et al. 2002). Resistance to azoxystrobin has been found in A. alternata, A. tenuissima, A. arborescens, and A. solani (Ma and Michailides 2004; Ma et al. 2003; Pasche et al. 2004). Three singlesite mutations in gene $c y t b$ (F129L, G137R, and G143A) have been found in agricultural systems that confer resistance to azoxystrobin (Fisher and Meunier 2008). The F129L mutation confers partial resistance and replaces a phenylalanine with a leucine at codon 129 in the $c y t b$ gene and has been found in A. solani (Pasche et al. 2005). The G143A mutation confers complete resistance and replaces a guanine with an alanine at $c y t b$ codon 143 and has been found in various Alternaria spp. (Ma et al. 2003; Vega et al. 2012). The G143 mutation is much more prevalent and the cause of the QoI resistance in many plant pathogens (Gisi et al. 2002). The G137R mutation is less common but has been found to confer partial resistance by exchanging a glycine with an arginine at $c y t b$ codon 137 (Sierotzki et al. 2007). The goal of this study is to determine how diverse the population of $A$. 
brassicicola is for New York State and to determine the level of sensitivity of New York isolates of A. brassicicola to azoxystrobin.

\section{Materials and Methods}

Isolates used in this study. In total, 49 A. brassicicola isolates were collected over a period of years and locations across New York State (Table 1). Small pieces of plant tissue from the edge of a leaf lesion were disinfested and rinsed in sterile distilled water before plating on potato dextrose agar (Difco PDA; Becton, Dickinson, and Company, Franklin Lakes, NJ). Single conidial isolates were obtained from each culture with standard dilution procedures.

DNA extraction and confirmation of $A$. brassicicola isolates. Small amounts of mycelia from the single conidial isolates were scraped off the agar in each plate using a sterile pipette tip and were placed in $50 \mathrm{ml}$ of potato dextrose broth in 200-ml Erlenmeyer flasks and grown for 5 to 10 days at room temperature $\left(22^{\circ} \mathrm{C}\right)$ on a shaker at $100 \mathrm{rpm}$. The mycelium was then collected by vacuum filtration. DNA extractions were performed using the Qiagen DNeasy Plant Mini Kit according to the manufacturer's instructions, with slight modifications (Qiagen, Valencia, CA). In order to disrupt the tissue, 35 to $100 \mathrm{mg}$ of wet mycelia was placed in a $2-\mathrm{ml}$ safe-lock, roundbottom centrifuge tube with one 5-mm sterile stainless steel grinding bead (Qiagen) and shaken in a Qiagen Tissue-Lyser at 30 cycles per second for $30 \mathrm{~s}$. After the final wash step with buffer AW2, a 1-min centrifuge cycle was added to help dry the filter. The incubation with AE elution buffer was extended to $15 \mathrm{~min}$ for the final step of the kit protocol (Dunn et al. 2010). Quantity and quality of the extracted DNA was determined using a NanoDrop Spectrophotometer ND1000 (NanoDrop Technologies, Wilmington, DE).

Each single conidial isolate was confirmed to be A. brassicicola with polymerase chain reaction (PCR) using previously designed species-specific primers ABRA1 and ABRA2 (Iacomi-Vasilescu et al. 2002). Each 25- $\mu$ l reaction contained $1 \mu l$ of DNA (10 to $50 \mathrm{ng}$ ), $0.2 \mu \mathrm{M}$ each primer, $200 \mu \mathrm{M}$ each $\mathrm{dNTP}, 1 \times$ Green GoTaq reaction buffer containing $1.5 \mathrm{mM} \mathrm{MgCl}_{2}$, and $1.0 \mathrm{U}$ of GoTaq DNA polymerase (Promega Corp., Madison, WI). PCR assays were conducted in a BioRad C1000 Touch Thermal Cycler (Bio-Rad, Hercules, CA) with an initial denaturation of $3 \mathrm{~min}$ at $94^{\circ} \mathrm{C}$; followed by 35 cycles of $30 \mathrm{~s}$ at $94^{\circ} \mathrm{C}$, $50 \mathrm{~s}$ at $55^{\circ} \mathrm{C}$, and $1 \mathrm{~min}$ at $72^{\circ} \mathrm{C}$; and a final elongation at $72^{\circ} \mathrm{C}$ for $10 \mathrm{~min}$. PCR assays were verified by running on a $1.5 \%$ agarose gel with $1 \%$ ethidium bromide. Each isolate was also tested with primers ABRE1 and ABRE3 previously developed for A. brassicae, which has a similar appearance to A. brassicicola in culture (Iacomi-Vasilescu et al. 2002). The same PCR conditions that were used for the ABRA1/ABRA2 primer pair were also used for the ABRE1/ABRE3 primer pair.

Simple-sequence repeat analyses. Ten microsatellite loci were used to determine genotypes for 49 A. brassicicola isolates using primer pairs previously designed for A. brassicicola (Avenot et al. 2005). Forward primers for each pair were fluorescently labeled with one of the following dyes at the $5^{\prime}$ end: 6-FAM, VIC, NED, or PET (Applied Biosystems, Grand Island, NY). Primer pairs were used in separate $25-\mu 1 \mathrm{PCR}$ assays containing $10 \mathrm{ng}$ of DNA, $0.4 \mu \mathrm{M}$ each primer, $200 \mu \mathrm{M}$ each dNTP, $1 \times$ Green GoTaq reaction buffer containing $1.5 \mathrm{mM} \mathrm{MgCl}_{2}$, and $1.0 \mathrm{U}$ of GoTaq DNA polymerase (Promega Corp.). PCR assays were conducted in a Bio-Rad C1000 Touch Thermal Cycler with an initial denaturation of 3 min at $94^{\circ} \mathrm{C}$; followed by 30 cycles of $30 \mathrm{~s}$ at $94^{\circ} \mathrm{C}, 30 \mathrm{~s}$ at the appropriate annealing temperature (see below), and $30 \mathrm{~s}$ at $72^{\circ} \mathrm{C}$; with a final elongation at $72^{\circ} \mathrm{C}$ for $10 \mathrm{~min}$. Primers for loci Abmic1, Abmic2, Abmic3, Abmic4, Abmic5, and Abmic7 were amplified with an annealing temperature of $55^{\circ} \mathrm{C}$. Loci Abmic9 and Abmic 11 were amplified with an annealing temperature of $60^{\circ} \mathrm{C}$, Abmic 8 at $58^{\circ} \mathrm{C}$, and Abmic 10 at $56^{\circ} \mathrm{C}$ (Avenot et al. 2005). For analysis, $1 \mu \mathrm{l}$ of PCR product was added to $0.04 \mu \mathrm{l}$ of GeneScan-500 LIZ size standard (Applied Biosystems) and $15 \mu \mathrm{l}$ of formamide (Sigma-Aldrich, St. Louis). Fragments were sized using an ABI 3730xl DNA Analyzer at the Cornell University Institute of Biotechnology Genomic Facility. Electropherograms were viewed in PeakScanner (Applied Biosystems) and alleles were scored manually.

Statistical analysis. The RStudio statistical software, version 0.99.878 (RStudio Team 2015), was used along with the poppr package, version 2.1.0 (Kamvar et al. 2014), to determine the number of multilocus genotypes (MLG) in the 49 isolates using allele sizes from the 10 loci assayed. An analysis of molecular variance (AMOVA) was conducted using poppr to estimate the proportion of variation observed from differences within and among counties, years, and isolates from different host plants (Excoffier et al. 1992). Significance was determined using 999 permutations. The poppr package was used to create a dendrogram of all isolates using the unweighted pair-group method with arithmetic mean analysis and Bruvo's distance with 999 bootstraps and cutoff value of $50 \%$. Minimum spanning networks were also created for host, county, and year collected using Bruvo's distance. The poppr package was also used to calculate

Table 1. Sensitivity of New York State isolates of Alternaria brassicicola with the year they were collected, the county where they were collected, the host plant from which they were isolated, and the concentration of azoxystrobin that effectively reduced spore germination by $50 \%\left(\mathrm{EC}_{50}\right)$

\begin{tabular}{|c|c|c|c|c|}
\hline Isolate & Year collected & County & Host plant & $\mathrm{EC}_{50}(\mu \mathrm{g} / \mathrm{ml})^{\mathrm{a}}$ \\
\hline $759 \mathrm{~B}$ & 1994 & Unknown & Cabbage & 0.75 \\
\hline $914 \mathrm{~A}$ & 1997 & Ontario & Pennycress & 2.11 \\
\hline $955 \mathrm{~A}$ & 2000 & Unknown & Cabbage & 2.25 \\
\hline $990 \mathrm{~A}$ & 2001 & Yates & Cabbage & 2.23 \\
\hline 997A & 2002 & Dutchess & Cabbage & 7.78 \\
\hline $1002 \mathrm{~A}$ & 2002 & Cortland & Cabbage & 14.12 \\
\hline $1121 \mathrm{~A}$ & 2010 & Ontario & Cabbage & 1.72 \\
\hline $1122 \mathrm{~A}$ & 2010 & Orleans & Cabbage & 2.29 \\
\hline $1123 \mathrm{~A}$ & 2010 & Wayne & Cabbage & 4.61 \\
\hline $1126 \mathrm{~A}$ & 2010 & Ontario & Cabbage & 6.71 \\
\hline $1128 \mathrm{~A}$ & 2010 & Ontario & Cauliflower & - \\
\hline $1130 \mathrm{~A}$ & 2010 & Ontario & Cauliflower & 0.74 \\
\hline $1133 \mathrm{~A}$ & 2010 & Orleans & Cabbage & 1.02 \\
\hline $1135 \mathrm{~A}$ & 2010 & Monroe & Cauliflower & 7.76 \\
\hline $1136 \mathrm{~A}$ & 2010 & Monroe & Cabbage & 0.61 \\
\hline $1138 \mathrm{~A}$ & 2010 & Ontario & Cabbage & 5.59 \\
\hline $1139 \mathrm{~A}$ & 2010 & Ontario & Cabbage & 0.60 \\
\hline $1140 \mathrm{~A}$ & 2010 & Ontario & Cabbage & 0.65 \\
\hline $1141 \mathrm{~A}$ & 2010 & Ontario & Cabbage & 0.86 \\
\hline $1144 \mathrm{~A}$ & 2011 & Ulster & Kale & 0.86 \\
\hline $1146 \mathrm{~A}$ & 2011 & Suffolk & Brussels sprouts & 0.43 \\
\hline $1147 \mathrm{~A}$ & 2011 & Ontario & Cauliflower & 2.33 \\
\hline 1149A & 2011 & Ontario & Broccoli & 0.97 \\
\hline $1153 \mathrm{~A}$ & 2011 & Rensselaer & Cabbage & 1.12 \\
\hline $1155 \mathrm{~A}$ & 2011 & Ontario & Cabbage & 1.04 \\
\hline $1156 \mathrm{~A}$ & 2011 & Monroe & Cabbage & 1.43 \\
\hline $1157 \mathrm{~A}$ & 2011 & Ontario & Cabbage & 0.33 \\
\hline $1158 \mathrm{~A}$ & 2011 & Ontario & Cabbage & 7.12 \\
\hline $1160 \mathrm{~A}$ & 2011 & Ontario & Kale & 1.56 \\
\hline $1161 \mathrm{~A}$ & 2011 & Washington & Cabbage & 2.79 \\
\hline $1162 \mathrm{~A}$ & 2011 & Monroe & Brussels sprouts & 2.70 \\
\hline $1163 \mathrm{~A}$ & 2011 & Orleans & Cabbage & 0.22 \\
\hline $1164 \mathrm{~A}$ & 2011 & Orleans & Cabbage & 1.45 \\
\hline $1165 \mathrm{~A}$ & 2011 & Genessee & Broccoli & 0.49 \\
\hline $1166 \mathrm{~A}$ & 2011 & Genessee & Cauliflower & 0.66 \\
\hline $1167 \mathrm{~A}$ & 2011 & Genessee & Cabbage & 0.64 \\
\hline $1168 \mathrm{~A}$ & 2011 & Tompkins & Brussels sprouts & 0.99 \\
\hline $1169 \mathrm{~A}$ & 2011 & Tompkins & Brussels sprouts & 11.03 \\
\hline $1170 \mathrm{~A}$ & 2011 & Tompkins & Cabbage & 1.89 \\
\hline $1171 \mathrm{~A}$ & 2011 & Tompkins & Kale & 0.57 \\
\hline $1172 \mathrm{~A}$ & 2011 & Tompkins & Kale & 0.92 \\
\hline $1173 \mathrm{~A}$ & 2011 & Tompkins & Cabbage & 1.11 \\
\hline $1193 \mathrm{~A}$ & 2013 & Ontario & Cabbage & 0.28 \\
\hline $1195 \mathrm{~A}$ & 2013 & Genessee & Brussels sprouts & 2.68 \\
\hline $1196 \mathrm{~A}$ & 2013 & Genessee & Cauliflower & 1.56 \\
\hline $1198 \mathrm{~A}$ & 2013 & Genessee & Broccoli & 2.16 \\
\hline 1199A & 2013 & Erie & Broccoli & 5.13 \\
\hline $1200 \mathrm{~A}$ & 2013 & Ulster & Broccoli & - \\
\hline $14001 \mathrm{~A}$ & 2014 & St Lawrence & Cabbage & 0.29 \\
\hline
\end{tabular}

${ }^{\mathrm{a}} \mathrm{EC}_{50}$ was calculated using a probit analysis; - indicates isolates that were included in simple-sequence repeat analysis; however, they were lost prior to the azoxystrobin sensitivity screening. 
the following for the entire New York population: Shannon-Wiener's index of genetic diversity $\left(H^{\prime}\right)$ (Shannon 2001), Stoddart and Taylor's index of MLG diversity $(G)$ (Stoddart and Taylor 1988), Simpson's index of diversity $(\lambda)$ (Simpson 1949), evenness $\left(E_{5}\right)$ (Grünwald et al. 2003), and the index of association $\left(I_{A}\right)$ (Brown et al. 1980). Nei's index of gene diversity $\left(\mathrm{H}_{\text {exp }}\right)$ (Nei 1978) was also calculated after removing any nonpolymorphic loci.

Azoxystrobin in vitro sensitivity assay. Isolates were exposed to azoxystrobin (Sigma-Aldrich) by adding the chemical (dissolved in acetone) along with salicylic hydroxamic acid (SHAM; SigmaAldrich) dissolved in methanol to sterile water agar (1.5\%) that had been cooled to $55^{\circ} \mathrm{C}$ (Ma et al. 2003; Pasche et al. 2004). The final concentrations of azoxystrobin active ingredient (a.i.) in the water agar media were $25,10,1.0,0.1,0.01$, and $0.001 \mu \mathrm{g}$ a.i. $/ \mathrm{ml}$, while all media contained SHAM at $60 \mu \mathrm{g} / \mathrm{ml}$ (Vaghefi et al. 2016). Final concentrations of the solvents in the fungicide amended water agar did not exceed $0.25 \%$ (vol/vol). Control plates consisted of water agar and water agar amended with SHAM at $60 \mu \mathrm{g} / \mathrm{ml}$.

A. brassicicola isolates were tested for fungicide sensitivity to azoxystrobin by determining the effective concentration at which $50 \%$ spore germination was inhibited $\left(\mathrm{EC}_{50}\right)$. A spore suspension was made from a 7-day-old culture grown on PDA at room temperature with $15 \mathrm{~h}$ of daylight by adding $5 \mathrm{ml}$ of sterile distilled water to the culture and dislodging spores with a sterile, L-shaped spreader. The suspension was then passed through a double layer of sterile cheesecloth. Concentration of spore suspension was determined with a hemocytometer and adjusted to $10^{4}$ conidia/ml. The suspension $(50 \mu \mathrm{l})$ was spread onto water agar amended with fungicide and SHAM. Plates were stored in darkness for $24 \mathrm{~h}$ at room temperature. After $24 \mathrm{~h}, 100$ conidia were counted per plate by placing agar squares on a slide, and examined microscopically. A conidium was considered germinated if the germ tube was longer than or equal in length to the conidium (Rogers and Stevenson 2010). The entire experiment was repeated, for a total of two plates (100 conidia/plate) that were counted for each isolate at each fungicide concentration along with the water agar and water agar plus SHAM controls.

The Statistical Analysis System (SAS, version 9.4; Cary, NC) was used to perform a $t$ test across all isolates comparing the water agar control and the water agar plus SHAM control to determine whether the SHAM resulted in any germination inhibition. A probit analysis was performed using SAS to calculate the $\mathrm{EC}_{50}$ based on the water agar control.

cytb Sequencing. Primers were developed for the A. brassicicola $c y t b$ gene targeting the hotspots for mutations known to confer azoxystrobin resistance, F129L and G143A. Two sets of primers were designed due to a large intron (approximate 1,315 bp) located after codon 131. Primers CytB129.2F (5'-AAC CCA TAG ATA GTG CGT CTA GGA-3') and CytB129.2R (5'-ATC TAC GCG GAG GTG ATA CAG-3') were used to amplify a fragment of the $c y t b$ gene

Table 2. Number of alleles detected for Alternaria brassicicola isolates for each microsatellite locus

\begin{tabular}{lrcl}
\hline $\begin{array}{l}\text { Microsatellite } \\
\text { marker }^{\mathbf{a}}\end{array}$ & $\boldsymbol{N}^{\mathbf{b}}$ & $\mathbf{H}_{\text {exp }} \mathbf{c}$ & \multicolumn{1}{c}{ Size of alleles (bp) } \\
\hline Abmic1 & 2 & 0.12 & 115,117 \\
Abmic2 & 2 & 0.33 & 124,126 \\
Abmic3 & 3 & 0.53 & $105,107,109$ \\
Abmic4 & 6 & 0.62 & $76,92,94,96,115,135$ \\
Abmic5 & 1 & - & 97 \\
Abmic7 & 1 & - & 107 \\
Abmic8 & 5 & 0.66 & $146,148,150,152,156$ \\
Abmic9 & 9 & 0.80 & $76,90,92,94,96,98,100,102,104$ \\
Abmic10 & 2 & 0.38 & 151,154 \\
Abmic11 & 10 & 0.85 & $180,183,185,188,191,197,200$, \\
& & & $206,209,212$
\end{tabular}

a Microsatellite markers developed by Avenot et al. (2005).
b Number of alleles for individual microsatellite loci.
c Nei's index of gene diversity $\left(\mathrm{H}_{\text {exp }}\right)=1-\Sigma p_{i}{ }^{2}$, where $p_{i}$ is the frequency of
the $i$ th allele at the given locus (Nei 1978). containing codon 129 and primers AbCytB101F (5'-TTG GCG ATG TTA GTG AAT ACG A-3') and AbCytB92R (5'-ATA CCC ATC TCC ATC AAT TAG TCC-3') were used to amplify a fragment of the $c y t b$ gene containing codons 137 and 143. For these PCR amplifications, each $25-\mu 1$ reaction contained $30 \mathrm{ng}$ of genomic DNA, $0.2 \mu \mathrm{M}$ each primer, and $1 \times$ EmeraldAmp GT PCR Master Mix (Takara Clontech Laboratories, Mountain View, CA). PCR assays were conducted in a Bio-Rad C1000 Touch Thermal Cycler (Bio$\mathrm{Rad}$ ) with an initial denaturation of $3 \mathrm{~min}$ at $94^{\circ} \mathrm{C}$; followed by 35 cycles of $30 \mathrm{~s}$ at $94^{\circ} \mathrm{C}, 30 \mathrm{~s}$ at $59^{\circ} \mathrm{C}$, and $30 \mathrm{~s}$ at $72^{\circ} \mathrm{C}$; and a final elongation at $72^{\circ} \mathrm{C}$ for $10 \mathrm{~min}$. PCR assays were verified by running on a $1.5 \%$ agarose gel with $1 \%$ GelRed Nucleic Acid Stain (Biotium, Hayward, CA). PCR products were then purified using Zymo DNA Clean and Concentrator kit (Zymo Research Corp., Irvine, CA), and sequenced at the Cornell University Institute of Biotechnology Genomic Facility. Sequences were analyzed using Molecular Evolutionary Genetics Analysis (Tamura et al. 2013).

\section{Results}

Simple-sequence repeats genotyping. In total, 49 isolates collected in New York State were used in the diversity study (Table 1). In all, 8 of the 10 microsatellite loci examined were found to be polymorphic, with a total of 44 MLG observed. The number of alleles found for each of the loci ranged from 1 to 10 alleles (Table 2). In all cases, one allele was amplified per isolate per locus. Five of the MLG were identified twice. In four of the five shared MLG, there was a common host, county, or year of collection (Table 3). Results from the AMOVA revealed that there was no significant genetic differentiation between or within counties and years of collection. The AMOVA did reveal significant genetic differentiation $(P<0.05)$ among isolates from different host plants and accounted for $4.36 \%$ of the variation in the New York population. Most of the variation observed occurred within samples.

The dendrogram and minimum spanning networks revealed little structure because no clustering was observed by host, county, or year of collection. There were only eight bootstrap values greater than $50 \%$ identified (data not shown). Measurements for genotypic diversity were high as determined by $H^{\prime}, G$, and $\lambda$ (Table 4 ). $\mathrm{H}_{\text {exp }}$ was high for the entire population (Table 4). The genotypes occur at approximately the same frequency in the population given the high $E_{5}$ (Table 4$)$. The $I_{A}$ was significant $(P>0.05)$, indicating that the population observed is in linkage disequilibrium.

Sensitivity to azoxystrobin and $c y t b$ sequencing. No significant differences were observed between the water agar control and the water agar plus SHAM control. For the 47 isolates tested, the $\mathrm{EC}_{50}$ values for azoxystrobin ranged from 0.22 to 14.12 a.i. $\mu \mathrm{g} / \mathrm{ml}$, with a mean $\mathrm{EC}_{50}$ value of $2.49 \mu \mathrm{g} / \mathrm{ml}$. Of the 47 isolates, 19 were highly sensitive $\left(\mathrm{EC}_{50}\right.$ value $\left.<1.0 \mu \mathrm{g} / \mathrm{ml}\right)$ and 20 of the 47 isolates were moderately sensitive $(<5.0 \mu \mathrm{g} / \mathrm{ml})$. The remaining eight isolates were less sensitive, with $\mathrm{EC}_{50}$ values of 5.13 to $14.12 \mu \mathrm{g} / \mathrm{ml}$. Due to the range of $\mathrm{EC}_{50}$ values, partial sequences for the $c y t b$ gene were obtained for all isolates tested with azoxystrobin. Mutations known to confer resistance to azoxystrobin were not found in any of the 47 isolates studied. All of the 47 isolates were found to have a large intron (approximately 1,315 bp). No heteroplasmy was observed in

Table 3. Collection details for the Alternaria brassicicola isolates that had the same multilocus genotypes (MLG) as determined by 10 microsatellite loci

\begin{tabular}{lccll}
\hline MLG & Isolate & Year & County & \multicolumn{1}{c}{ Host } \\
\hline MLG 5 & $1136 \mathrm{~A}$ & 2010 & Monroe & Cabbage \\
& $1141 \mathrm{~A}$ & 2010 & Ontario & Cabbage \\
MLG 6 & $1167 \mathrm{~A}$ & 2011 & Genessee & Cabbage \\
& $1198 \mathrm{~A}$ & 2013 & Genessee & Broccoli \\
MLG 14 & $1169 \mathrm{~A}$ & 2011 & Tompkins & Brussels Sprouts \\
& $1193 \mathrm{~A}$ & 2013 & Ontario & Cabbage \\
MLG 27 & $990 \mathrm{~A}$ & 2001 & Yates & Cabbage \\
& $1138 \mathrm{~A}$ & 2010 & Ontario & Cabbage \\
MLG 37 & $1135 \mathrm{~A}$ & 2010 & Monroe & Cauliflower \\
& $1196 \mathrm{~A}$ & 2013 & Genessee & Cauliflower \\
\hline
\end{tabular}


the electropherograms for any of the isolates at the locations for the three known mutations.

\section{Discussion}

This study revealed that the New York State population of A. brassicicola has high genotypic diversity as well as high gene diversity. Of 49 isolates, 44 unique MLG were found and confirmed by indices of genotypic diversity. The mean gene diversity, which is calculated using the number and frequencies of alleles at each locus, was also high, with an estimate of 0.53 for the population. High levels of genotypic diversity is one of the major outcomes of having a recombinant population, along with random association between alleles at different loci (Milgroom 1996). The New York State population had high levels of diversity; however, the $I_{A}$ calculated for the New York population was significantly different from zero, indicating linkage disequilibrium and, thus, a nonrandom association of loci. The $I_{A}$ indicates that asexual reproduction is important for the population. A population can be in linkage disequilibrium due to a lack of recombination or other factors such as selection, gene flow, drift, or linkage (Milgroom 1996). Maynard Smith et al. (2000) indicated that disequilibrium may occur because recombination is rare or absent or because there is geographical structuring within the populations. The New York isolates were analyzed as one population due to the lack of population structure, because there was little structure or clustering by host plant, year of collection, or county from which the isolate was collected. Lack of population structure might be a result of multiple introductions through seedborne inoculum (Iacomi-Vasilescu et al. 2002, 2004). Most of the variation observed was among the individuals.

Similar studies have also seen high levels of diversity for A. brassicicola populations; however, the populations studied were also found to be in significant linkage disequilibrium, indicating that clonal reproduction still exists among the populations. (Bock et al. 2005; Linde et al. 2010). Bock et al. (2005) suggested that the high levels of diversity observed were due to recombination but suggested that the populations remained in linkage disequilibrium due to the fact that recombination happens only on occasion or, perhaps, numbers have not built up for the population to be in linkage equilibrium. Linde et al. (2010) also found high levels of genetic diversity and found that all but two of the populations were in linkage equilibrium.

Other Alternaria spp. in addition to A. brassicicola have also shown indication of recombination or high diversity (Gannibal et al. 2007; Morris et al. 2000; Prasad et al. 2009; van der Waals et al. 2004). Distinct subpopulations of A. alternata sensu lato on citrus were found to be in linkage disequilibrium; however, when one of the subpopulations was examined further by dividing into two groups, one of the groups was found to be in linkage equilibrium even though only one mating type existed (Stewart et al. 2013). The authors suggested that a parasexual life cycle was occurring in this population.

The high levels of genotypic diversity seen in A. brassicicola isolates from New York State could be indicative of sexual reproduction; however, no sexual stage has been reported and, even though the population does not appear to be clonal, this does not mean that sexual reproduction is occurring in New York State. Future studies that include a larger sample size and sampling by region may help detect whether there is any geographical structuring within populations.

There is no evidence for azoxystrobin resistance in New York at this time because we did not identify mutations at locations F129L, G137R, and G143A; however, a range of sensitivities was observed for A. brassicicola during in vitro assays. This is the first study that investigated the sensitivity of $A$. brassicicola to azoxystrobin, and the $\mathrm{EC}_{50}$ values can serve as a baseline for A. brassicicola to azoxystrobin. The range of $\mathrm{EC}_{50}$ values in $A$. brassicicola was higher than what is typically observed for baseline sensitivities in other Alternaria spp. In carrot, baseline sensitivities for $A$. dauci to azoxystrobin were much lower and ranged from 0.01 to $0.37 \mu \mathrm{g} / \mathrm{ml}$ (Rogers and Stevenson 2010). Sensitive Alternaria isolates from pistachio had $\mathrm{EC}_{50}$ values of 0.008 to $0.045 \mu \mathrm{g} / \mathrm{ml}$, whereas the resistant isolates had $\mathrm{EC}_{50}$ values greater than $100 \mu \mathrm{g} / \mathrm{ml}$ and were found to contain the G143A mutation in the cytb gene (Ma et al. 2003). Pasche et al. (2005) reported that $A$. solani isolates sensitive to azoxystrobin had a mean $\mathrm{EC}_{50}$ value of $0.0324 \mu \mathrm{g} / \mathrm{ml}$, whereas isolates containing the F129L mutation had a mean $\mathrm{EC}_{50}$ value of $0.3788 \mu \mathrm{g} / \mathrm{ml}$. Because no mutations were found and the $\mathrm{EC}_{50}$ values were relatively low, we believe that no resistance has been detected at this time. Future studies are needed to assess the field efficacy of azoxystrobin against $A$. brassicicola.

In addition to determining the baseline sensitivity of $A$. brassicicola to azoxystrobin, this study also identified a large intron in the $c y t b$ gene after codon 131. Other studies have shown that the presence or lack of introns can have an effect on the presence of point mutations known to confer resistance to QoI fungicides (Grasso et al. 2006a). In other pathosystems, introns located after codon 143 appear to prevent the G143A mutation from developing (FernándezOrtuño et al. 2008; Grasso et al. 2006b; Jiang et al. 2009; Samuel et al. 2011). Leiminger et al. (2014) found two genotypes for the cytb gene in A. solani isolates in Germany, with genotype I containing introns after codon 126 and 143 and genotype II with an intron after codon 131. They found that the genotype II isolates containing the intron after codon 131 also had the mutation for F129L. Because no $c y t b$ gene mutations were identified in the New York isolates tested, it is not known whether the presence of the intron has an effect on the presence of mutations known to confer resistance.

Isolates of A. brassicicola from New York were found to be highly diverse, potentially indicating recombination; however, linkage disequilibrium indicated that asexual reproduction appears to be important for the population. The population was sensitive to azoxystrobin at this time but later studies with larger populations need to be conducted to further clarify the diversity and azoxystrobin sensitivity of this pathogen in New York.

Table 4. Population size, number of multilocus genotypes (MLG), genotypic diversity, and index of association $\left(I_{A}\right)$ as determined for New York State isolates of Alternaria brassicicola with 10 microsatellite loci

\begin{tabular}{|c|c|c|c|c|c|c|c|c|c|}
\hline Isolates & $N^{\mathrm{a}}$ & MLG $^{\mathbf{b}}$ & $N_{1}{ }^{\mathrm{c}}$ & $G^{\mathrm{d}}$ & $1-\lambda^{\mathrm{e}}$ & $\mathbf{H}_{\text {exp }} \mathbf{f}$ & $E_{5} \mathrm{~g}$ & $I_{A}{ }^{\mathrm{h}}$ & $P$ value $^{\mathrm{i}}$ \\
\hline A. brassicicola & 49 & 44 & 42.52 & 40.7 & 0.975 & 0.53 & 0.956 & 0.143 & 0.028 \\
\hline $\begin{array}{l}\text { a Total number } \\
\text { b Number of Ml } \\
\text { c Proportional S } \\
\text { (Shannon 200 } \\
\text { d Stoddart and T } \\
\text { can have a mi } \\
\text { e Simpson's ind } \\
\text { f Mean Nei's in } \\
\text { given locus; st } \\
\text { g Evenness }\left(E_{5}\right) \\
\text { h Index of assoc } \\
\text { i } P \text { value for } L\end{array}$ & $\begin{array}{l}\text { tes us } \\
\text { tified } \\
\text { l-Wier } \\
\text { stic ce } \\
\text { index } \\
\text { value } \\
\text { iversit } \\
\text { sene d } \\
\text { can ha } \\
1) /(N \\
A)=( \\
\text { ted us }\end{array}$ & $\begin{array}{l}\text { is study. } \\
\text { e alleles } \\
\text { dex of get } \\
\text { a minimu } \\
\text { G diversit } \\
\text { d maximı } \\
\sum p_{i}{ }^{2} \text {, whe } \\
\text { (Nei } 1978 \\
\text { lue from } \\
\text { Grünwalc } \\
\text { - 1, where } \\
p r \text { (Kamy }\end{array}$ & $\begin{array}{l}\text { crosatel } \\
\text { ersity }( \\
\text { of } 1 \text { an } \\
1 / \Sigma p_{i}^{2}, \\
\text { of the } \\
\text { he frequ } \\
\text { ated afte } \\
003) \text {; st } \\
\text { e observ } \\
2014 \text { ) }\end{array}$ & $\begin{array}{l}=\mathrm{e}^{H^{\prime}} \\
\text { mum v } \\
\text { is the } \\
\text { ion siz } \\
\text { the } i \text { th } \\
\text { ing no } \\
\text { an hav } \\
\text { ince of } \\
\text { ance }\end{array}$ & $\begin{array}{l}\text { Id et al. } \\
\text { he popul } \\
\text { y of the } i t \\
\text { pe in the } \\
\text { orphic loc } \\
\text { from } 0 \\
\text { ces betwe } \\
\text { d with } 99\end{array}$ & $\begin{array}{l}=-\Sigma_{i}( \\
\mathrm{e}(N) \\
\text { ype in th } \\
\text { on ( } \mathrm{Sim} \\
=1-\Sigma\end{array}$ & $\begin{array}{l}\text { where } p \\
\text { lation (S } \\
\text { 49); stat } \\
\text { re } p_{i} \text { is t } \\
\text { the expe }\end{array}$ & $\begin{array}{l}\text { frequen } \\
\text { and Tay } \\
\text { have a } \\
\text { ency of } \\
\text { riance (I }\end{array}$ & $\begin{array}{l}i \text { th MLG } \\
\text { 8); statistic } \\
\text { om } 0 \text { to } 1 . \\
\text { llele at the } \\
\text { tal. 1980). }\end{array}$ \\
\hline
\end{tabular}




\section{Acknowledgments}

This study was supported, in part, by the New York State Cabbage Research and Development Program. We thank K. Cox, S. Pethybridge, F. Hay, N. Vaghefi, S. Villani, A. Dunn, and Z. Hansen for thoughtful conversations and suggestions about experimental design and data analyses; and H. Lange and A. Muhich for technical assistance.

\section{Literature Cited}

Adachi, Y., Watanabe, H., Tanabe, K., Doke, N., Nishimura, S., and Tsuge, T. 1993. Nuclear ribosomal DNA as a probe for genetic variability in the Japanese pear pathotype of Alternaria alternata. Appl. Environ. Microbiol. 59:3197-3205.

Aradhya, M. K., Chan, H. M., and Parfitt, D. E. 2001. Genetic variability in the pistachio late blight fungus, Alternaria alternata. Mycol. Res. 105:300-306.

Avenot, H., Dongo, A., Bataillé-Simoneau, N., Iacomi-Vasilescu, B., Hamon, B., Peltier, D., and Simoneau, P. 2005. Isolation of 12 polymorphic microsatellite loci in the phytopathogenic fungus Alternaria brassicicola. Mol. Ecol. Notes 5: 948-950.

Bartlett, D. W., Clough, J. M., Godwin, J. R., Hall, A. A., Hamer, M., and ParrDobrzanski, B. 2002. The strobilurin fungicides. Pest Manage. Sci. 58:649-662.

Bock, C. H., Thrall, P. H., and Burdon, J. J. 2005. Genetic structure of populations of Alternaria brassicicola suggests the occurrence of sexual recombination. Mycol. Res. 109:227-236.

Brown, A. H., Feldman, M. W., and Nevo, E. 1980. Multilocus structure of natural populations of Hordeum spontaneum. Genetics 96:523-536.

Chen, L. Y., Price, T. V., and Park-Ng, Z. 2003. Conidial dispersal by Alternaria brassicicola on Chinese cabbage (Brassica pekinensis) in the field and under simulated conditions. Plant Pathol. 52:536-545.

Cobb, A. C., and Dillard, H. R. 1998. Thlaspi arvense, a new host for Alternaria brassicicola. Plant Dis. 82:960.

Dillard, H. R., Cobb, A. C., and Lamboy, J. S. 1998. Transmission of Alternaria brassicicola to cabbage by flea beetles (Phyllotreta cruciferae). Plant Dis. 82:153-157.

Dunn, A. R., Milgroom, M. G., Meitz, J. C., McLeod, A., Fry, W. E., McGrath, M. T., Dillard, H. R., and Smart, C. D. 2010. Population structure and resistance to mefenoxam of Phytophthora capsici in New York State. Plant Dis. 94: 1461-1468.

Excoffier, L., Smouse, P. E., and Quattro, J. M. 1992. Analysis of molecular variance inferred from metric distances among DNA haplotypes: Application to human mitochondrial DNA restriction data. Genetics 131:479-491.

Fernández-Ortuño, D., Torés, J. A., de Vicente, A., and Pérez-García, A. 2008. Mechanisms of resistance to QoI fungicides in phytopathogenic fungi. Int. Microbiol. 11:1-9.

Fisher, N., and Meunier, B. 2008. Molecular basis of resistance to cytochrome bc1 inhibitors. FEMS Yeast Res. 8:183-192.

Gannibal, P. B., Klemsdal, S. S., and Levitin, M. M. 2007. AFLP analysis of Russian Alternaria tenuissima populations from wheat kernels and other hosts. Eur. J. Plant Pathol. 119:175-182.

Gisi, U., Sierotzki, H., Cook, A., and McCaffery, A. 2002. Mechanisms influencing the evolution of resistance to Qo inhibitor fungicides. Pest Manage. Sci. 58: 859-867.

Grasso, V., Palermo, S., Sierotzki, H., Garibaldi, A., and Gisi, U. 2006a. Cytochrome $b$ gene structure and consequences for resistance to Qo inhibitor fungicides in plant pathogens. Pest Manage. Sci. 62:465-472.

Grasso, V., Sierotzki, H., Garibaldi, A., and Gisi, U. 2006b. Characterization of the cytochrome $b$ gene fragment of Puccinia species responsible for the binding site of QoI fungicides. Pestic. Biochem. Physiol. 84:72-82.

Grünwald, N. J., Goodwin, S. B., Milgroom, M. G., and Fry, W. E. 2003. Analysis of genotypic diversity data for populations of microorganisms. Phytopathology 93:738-746.

Humpherson-Jones, F. M. 1989. Survival of Alternaria brassicae and Alternaria brassicicola on crop debris of oilseed rape and cabbage. Ann. Appl. Biol. 115:45-50.

Humpherson-Jones, F. M., and Phelps, K. 1989. Climatic factors influencing spore production in Alternaria brassicae and Alternaria brassicicola. Ann. Appl. Biol. 114:449-458.

Iacomi-Vasilescu, B., Avenot, H., Bataillé-Simoneau, N., Laurent, E., Guénard, M., and Simoneau, P. 2004. In vitro fungicide sensitivity of Alternaria species pathogenic to crucifers and identification of Alternaria brassicicola field isolates highly resistant to both dicarboximides and phenylpyrroles. Crop Prot. 23:481-488.

Iacomi-Vasilescu, B., Blancard, D., Guénard, M., Molinero-Demilly, V., Laurent, E., and Simoneau, P. 2002. Development of a PCR-based diagnostic assay for detecting pathogenic Alternaria species in cruciferous seeds. Seed Sci. Technol. 30:87-95.

Jiang, J., Ding, L., Michailides, T. J., Li, H., and Ma, Z. 2009. Molecular characterization of field azoxystrobin-resistant isolates of Botrytis cinerea. Pestic. Biochem. Physiol. 93:72-76.

Kamvar, Z. N., Tabima, J. F., and Grünwald, N. J. 2014. Poppr: An R package for genetic analysis of populations with clonal, partially clonal, and/or sexual reproduction. PeerJ 2:e281.

Köhl, J., van Tongeren, C. A. M., Groenenboom-de Haas, B. H., van Hoof, R. A., Driessen, R., and van der Heijden, L. 2010. Epidemiology of dark leaf spot caused by Alternaria brassicicola and A. brassicae in organic seed production of cauliflower. Plant Pathol. 59:358-367.

Köhl, J., Vlaswinkel, M., Groenenboom-de Haas, B. H., Kastelein, P., van Hoof, R. A., van der Wolf, J. M., and Krijger, M. 2011. Survival of pathogens of Brussels sprouts (Brassica oleracea Gemmifera Group) in crop residues. Plant Pathol. 60:661-670.

Leiminger, J. H., Adolf, B., and Hausladen, H. 2014. Occurrence of the F129L mutation in Alternaria solani populations in Germany in response to QoI application, and its effect on sensitivity. Plant Pathol. 63:640-650.

Linde, C. C., Liles, J. A., and Thrall, P. H. 2010. Expansion of genetic diversity in randomly mating founder populations of Alternaria brassicicola infecting Cakile maritima in Australia. Appl. Environ. Microbiol. 76:1946-1954.

Ma, Z., Felts, D., and Michailides, T. J. 2003. Resistance to azoxystrobin in Alternaria isolates from pistachio in California. Pestic. Biochem. Physiol. 77: 66-74.

Ma, Z., and Michailides, T. J. 2004. An allele-specific PCR assay for detecting azoxystrobin-resistant Alternaria isolates from pistachio in California. J. Phytopathol. 152:118-121.

Maynard Smith, J., Feil, E. J., and Smith, N. H. 2000. Population structure and evolutionary dynamics of pathogenic bacteria. BioEssays 22:1115-1122.

Meng, J.-W., Zhu, W., He, M.-H., Wu, E. J., Duan, G.-H., Xie, Y.-K., Jin, Y.-J., Yang, L.-N., Shang, L.-P., and Zhan, J. 2015a. Population genetic analysis reveals cryptic sex in the phytopathogenic fungus Alternaria alternata. Sci. Rep. 5:Ariticle number 18250. doi:10.1038/srep18250

Meng, J. W., Zhu, W., He, M. H., Wu, E. J., Yang, L. N., Shang, L. P., and Zhan, J. 2015b. High genotype diversity and lack of isolation by distance in the Alternaria solani populations from China. Plant Pathol. 64:434-441.

Milgroom, M. G. 1996. Recombination and the multilocus structure of fungal populations. Annu. Rev. Phytopathol. 34:457-477.

Morris, P. F., Connolly, M. S., and St Clair, D. A. 2000. Genetic diversity of Alternaria alternata isolated from tomato in California assessed using RAPDs. Mycol. Res. 104:286-292.

Nei, M. 1978. Estimation of average heterozygosity and genetic distance from a small number of individuals. Genetics 89:583-590.

Pasche, J. S., Piche, L. M., and Gudmestad, N. C. 2005. Effect of the F129L mutation in Alternaria solani on fungicides affecting mitochondrial respiration. Plant Dis. 89:269-278.

Pasche, J. S., Wharam, C. M., and Gudmestad, N. C. 2004. Shift in sensitivity of Alternaria solani in response to QoI fungicides. Plant Dis. 88:181-187.

Prasad, M. S. L., Sujatha, M., and Chander Rao, S. 2009. Analysis of cultural and genetic diversity in Alternaria helianthi and determination of pathogenic variability using wild Helianthus species. J. Phytopathol. 157:609-617.

Rogers, P. M., and Stevenson, W. R. 2010. Aggressiveness and fungicide sensitivity of Alternaria dauci from cultivated carrot. Plant Dis. 94:405-412.

RStudio Team. 2015. RStudio: Integrated Development for R. Online publication. https://www.rstudio.com

Samuel, S., Papayiannis, L. C., Leroch, M., Veloukas, T., Hahn, M., and Karaoglanidis, G. S. 2011. Evaluation of the incidence of the G143A mutation and cytb intron presence in the cytochrome $b c-1$ gene conferring QoI resistance in Botrytis cinerea populations from several hosts. Pest Manage. Sci. 67:1029-1036.

Shannon, C. E. 2001. A mathematical theory of communication. ACM SIGMOBILE Mob. Comput. Commun. Rev. 5:3-55.

Sierotzki, H., Frey, R., Wullschleger, J., Palermo, S., Karlin, S., Godwin, J. R., and Gisi, U. 2007. Cytochrome $b$ gene sequence and structure of Pyrenophora teres and $P$. tritici-repentis and implications of QoI resistance. Pest Manage. Sci. 63:225-233.

Simpson, E. 1949. Measure of Diversity. Nature 163:688

Stewart, J. E., Thomas, K. A., Lawrence, C. B., Dang, H., Pryor, B. M., Timmer, L. M., and Peever, T. L. 2013. Signatures of recombination in clonal lineages of the citrus brown spot pathogen, Alternaria alternata sensu lato. Phytopathology 103:741-749.

Stoddart, J. A., and Taylor, J. F. 1988. Genotypic diversity: Estimation and prediction in samples. Genetics 118:705-711.

Tamura, K., Stecher, G., Peterson, D., Filipski, A., and Kumar, S. 2013. MEGA6: Molecular evolutionary genetics analysis version 6.0. Mol. Biol. Evol. 30: 2725-2729.

USDA. 2015. New York Agriculture Statistics Annual Bulletin 2014-2015. Online publication. United States Department of Agriculture. http://www.nass.usda gov/Statistics_by_State/New_York/Publications/Annual_Statistical_Bulletin/ 2015/2014-2015 NY Annual Bulletin.pdf

Vaghefi, N., Hay, F. S., Kikkert, J. R., and Pethybridge, S. J. 2016. Genotypic diversity and resistance to azoxystrobin of Cercospora beticola on processing table beet in New York. Plant Dis. 100:1466-1473.

van der Waals, J. E., Korsten, L., and Slippers, B. 2004. Genetic diversity among Alternaria solani isolates from potatoes in South Africa. Plant Dis. 88:959-964.

Vega, B., Liberti, D., Harmon, P. F., and Dewdney, M. M. 2012. A rapid resazurinbased microtiter assay to evaluate QoI sensitivity for Alternaria alternata isolates and their molecular characterization. Plant Dis. 96:1262-1270.

Woudenberg, J. H. C., van der Merwe, N. A., Jurjević, Ž., Groenewald, J. Z., and Crous, P. W. 2015. Diversity and movement of indoor Alternaria alternata across the mainland USA. Fungal Genet. Biol. 81:62-72. 